\title{
Degree of Water Eutrophication in the Terminal Ba- sin of the Danube. Case Study
}

\author{
Cecilia NEAGU*
}

Department of Management, University of Agricultural Sciences and Veterinary Medicine Bucharest Călăraşi Faculty Branch, 1 Nicolae Titulescu, Călăraşi, Romania, Phone/Fax: +40242332077,

* corresponding author: cecilianeagu2005@yahoo.com

Bulletin USAMV series Agriculture 71(2)/2014

Print ISSN 1843-5246; Electronic ISSN 1843-5386

DOI 10.15835/buasvmcn-agr: 10367

\begin{abstract}
Due to human activity, there are some changes in the composition of surface waters, especially near the industrial plants and cities. Wastewater, insufficiently treated, affects negatively the quality of the emissary they reach.

The discharge of poorly treated municipal sewage and industrial surface waste water has serious consequences for the natural phenomenon of self-purification, water Borcea branch and the Danube are now reaching the limits of the natural possibilities of biogeochemical balance recovery.

In the present study two sources of waste water were taken into discussion, with important contribution of pollutants reaching the terminal basin of the Danube from the Waste Water Treatment of Călăraşi town and a meat processing plant, representative for the businesses in the county. The indicators followed in the study were: chemical consume of oxygen, biochemical consume of oxygen, ammonia nitrogen, total phosphorus.

In recent months, by the rehabilitations that have been already made in the treatment plant, the water quality discharged into the environment improved, from physical chemical point of view.

From the evolution of the main indicators analyzed, it is found out a decrease in content of organic substances and water eutrophication agents (total phosphorus and ammonium ion), their values reaching nearer to the standards required by the legislation in force.
\end{abstract}

Keywords: emissary, quality indicator, receiver, treated water.

\section{Abbreviations:}

$\mathbf{C B O}_{5}$ - biochemical consume of oxygen, in five days at $20^{\circ} \mathrm{C}$;

CCO-Cr - chemical consume of oxygen;

CMA - maximum concentrations admitted;

NTPA - technical norms for legislation application.

\section{INTRODUCTION}

A good knowledge of the phenomena of wastewater treatment, causes and their consequences, constitute a permanent call to an active attitude to protect and maintain the best possible the environment. Treatment plants are the main tool for cleaning polluted water, but if they do not work properly, lead to pollution of surface organic substances, nutrients and toxic substances.

Nitrogen and phosphorus are essential nutrients for the plants, but when their concentration exceeds a certain limit, they are considered pollutants and lead to excessive growth of aquatic plants, a process called eutrophication (Şchiopu et al., 2002).

Romania is the most important source quantitatively in the discharge of nutrients into the Black Sea, the waters on the entire territory drains into the Black Sea. Located in the terminal basin of the Danube, Călăraşi county contribute to this undesirable phenomenon. Călăraşi county area is $5088 \mathrm{~km}^{2}$, representing about $2.1 \%$ of Romania territory.

Studies on the Black Sea basin showed that the nutrient loads carried by the Danube is the main cause of eutrophication phenomenon, which is a serious problem in the north-western part of the Black Sea. The studies made under the Black Sea Environment Programme revealed that 58\% of 
the total nitrogen and $66 \%$ of the total phosphorus in waters reaching the Black Sea come from the Danube basin. The major ways of phosphorus entering the Danube basin are direct surface runoff from agricultural lands, soil erosion and effluents from wastewater treatment plants (in proportion of $33 \%, 31 \%$ and $30 \%$ ). The amount of nitrogen that is found in the same river basin from infiltration, leakage of agricultural land, from soil erosion and effluents from wastewater treatment plants, the proportion of approx. 35\% each. (Neagu, 2005).

The impact of the county agriculture on the environment is due to excessive use of chemical fertilizers, and because of improper application of pesticides, herbicides, fungicides, insecticides. The rule of application of nitrogen in crops chance is expensive and polluting. It is therefore twice harmful (Berca, 2008)

The impact of livestock is particularly strong, especially on farms that do not have treatment plants. The risk of nitrate pollution of groundwater is high, due to their high solubility in water in the soil. Actual pollution of soil and groundwater can be reached when harmful substances that reach the ground excess of the soil's capacity to degrade these substances (Berca, 2006).

The surface water pollution is an alteration of the physical, chemical or biological characteristics, caused directly or indirectly by human activity, after which water become unfit for normal use, for the purposes for which such use was possible before alteration appeared. The pollution sources of surface water can be divided into: pollution sources concentrated or organized (represented by municipal wastewater, discharging continuously, after a preliminary treatment of industrial wastewater, continuous or intermittent discharge and having or level of treatment), and the unorganized pollution sources (dispersed on the surface of the hydrographical basin of the respective water, which are made of water precipitation or surface runoff that washes the localities, land which waster were stored, agricultural land that were applied fertilizers or pesticides, and runoff from roads) (Şchiopu et al., 2002).

The effluents, wastewater, reach the receiver (in this case Borcea branch) and they flow into the environment (Danube), to which pollutants transmit. The pollution degree of the receivers is the highest in periods of drought, precisely in times needed to irrigate and it can act toxically on irrigated crops (Şchiopu et al., 2002).

The main sources of pollution of groundwater and surface water are also: warehouse platforms of household waste and manure, fertilizers and pesticides applied to crops, rural latrines and effluents from wastewater treatment plants in urban centers, waste from courts of every rural household (often located in close proximity to drinking water wells), etc. This makes most groundwater in the rural area are contaminated with significant concentrations of nitrate. Some drainage channels and surface water show clear signs of eutrophication, an indicator of the existence of phosphorus in these waters. The four main sources of nitrate pollution of groundwater are nitrates from manure and household waste mineralization, those coming from uncontrolled or poorly directed fermentation of waste and waste water from livestock, nitrates from fertilizers and those coming from humus mineralization (Code of Good Agricultural Practices, 2003).

\section{MATERIALS AND METHODS}

The river water quality is most affected by wastewater discharge. Therefore, the main practical measure to protect surface water quality is to monitor wastewater treatment, topic of the present paper.

Călărași county, due to the position of the terminal basin of the Danube, the wastewater discharged into the Borcea branch and then into the Danube, can be an important source of water eutrophication of the Black Sea, to which there is a distance of about $100 \mathrm{~km}$ (Cretu et al., 2012, 2013). The Danube is for the inhabitants of Călărași town the drinking water supply source, which implies a good treatment and water treatment supplied to the inhabitants of this town.

Due to the low rate of connection of the population to the systems of wastewater collection and treatment, the river pollution occurs through wastewater discharge through drains directly into the river and groundwater pollution by wastewater infiltration into the soil.

Wastewater pollutant load from urban areas has the greatest impact on the load of organic substances, materials in suspension, nutrients, detergents and extractable substances. 
In this paper I tried to identify the current status of wastewater reaching the Danube and Borcea branch and how these are treated.

The Agency for Environment Protection Călăraşi makes analyses for wastewater discharged into the environment. The indicators followed in this paper, those causing particular problems to the emissaries were: chemical consume of oxygen, biochemical consume of oxygen, ammonia nitrogen, total phosphorus.

The Danube river water quality is strongly influenced by the quality of wastewater before it is discharged into the receiver. These waters come from both economic activity and urban sewage.

The structure of wastewater discharged into Călăraşi town is:

- Domestic wastewater resulted from the technological process of the economic agents;

- Rainwater;

- Waste water from households.

The most important potential sources of pollution identified in Călăraşi county which affect Borcea branch are represented by the treatment plant of a meat processing factory and sausage manufacturing and wastewater treatment plant derived from the population of the town.

Council Directive 91/271/EEC of 21st May 1991 on urban waste water treatment, amended by Commission Directive $98 / 15 / \mathrm{EC}$ on $27^{\text {th }}$ February 1998, is the legal basis of the Community legislation on wastewater. This Directive was transposed entirely into the Romanian legislation by Government Decision No. 188/2002 for the approval of the norms of the conditions of wastewater discharge into the aquatic area, amended by Government Decision no. 352/2005 (Environment Report, 2012).

The central objective of the Directive is to protect the environment from the adverse effects of discharges of urban wastewater and wastewater from certain industrial sectors (mainly the processing and manufacture of food).

In Romania, the European legislation in the field of wastewater treatment and discharge into the aquatic area was implemented in the period 2002-2005, but further implementation steps are required to comply fully with the requirements of the Directive.

Considering both positioning Romania in the Danube basin and the Black Sea and the need for environment protection in these areas, Romania declared its entire territory as sensitive area. This decision is reflected in the fact that agglomerations with more than 10,000 inhabitants must provide an infrastructure for urban wastewater treatment enabling advanced treatment, especially in terms of the nutrients nitrogen and phosphorus. Regarding the degree of treatment, the secondary treatment (biological treatment) is a general rule for agglomerations of more than 10,000 population equivalents.

The Inhabitant equivalent (l.e) is the unit of measure and determine the size of biodegradable pollution from a human agglomeration. It is expressed as the average of that pollution from a person in one day - the directive set the value of 60 grams biochemical consume of oxygen at 5 days $\left(\mathrm{CBO}_{5}\right)$ per day. The calculation of equivalent inhabitants for a human agglomeration is given by the ratio of total load in $\mathrm{CBO}_{5}$ of wastewater and the value of $60 \mathrm{~g} \mathrm{CBO}_{5} /$ day corresponding to an inhabitant equivalent.

The terms of implementation of the Directive vary and depend on the size of agglomeration and its impact on receiving waters.

The transition deadline for implementing the Directive was established to $31^{\text {st }}$ December 2018, with intermediate deadlines for collection and treatment of urban waste water (Environment Report, 2012).

\section{RESULTS AND DISCUSSION}

Agency for Environment Protection Călăraşi has responsibilities regarding the monitoring of surface water quality, but it performs monthly surveys for wastewater evacuated by the economic agents, with significant impact on surface water quality.

According to data provided by Buzău Basin Administration - Ialomiţa, 2012, in Călăraşi county, the total volume of wastewater discharged from economic activities was 4015.312 thousand cubic meters/year, of which only 1028.99 thousand cubic meters/year were treated properly, the rest of 2986.322 thousand cubic meters/year is not treated properly (Environment Report, 2012).

The proof of problems regarding the water quality discharged into the emissary, is the result of tests performed at the Waste Water Treatment Plant Călăraşi, by the laboratory of the Agency for Environment Protection Călăraşi. 
Tab.1. Indicators of quality of evacuated wastewater at SC ECOAQUA SA Călăraşi in the period 20112013 (Environment reports, 2011, 2012, 2013)

\begin{tabular}{ccccccccc}
\hline & \multicolumn{7}{c}{ Indicators of quality (mg/dmc) - Annual averages } \\
\cline { 2 - 9 } Year & CCO-Cr & CMA $^{2}$ & CBO $_{5}$ & CMA & Ammonium & CMA & $\begin{array}{c}\text { Total } \\
\text { phosphorus }\end{array}$ & CMA \\
\hline 2011 & 128.02 & $\mathbf{1 2 5}$ & 58.55 & $\mathbf{2 5}$ & 27.04 & $2(3)$ & 3.47 & $1(2)$ \\
\hline 2012 & 127.38 & $\mathbf{1 2 5}$ & 58.35 & $\mathbf{2 5}$ & 26.94 & $2(3)$ & 3.67 & $1(2)$ \\
\hline 2013 & 127.97 & $\mathbf{1 2 5}$ & 58.22 & $\mathbf{2 5}$ & 26.032 & $2(3)$ & 3.32 & $1(2)$ \\
\hline
\end{tabular}

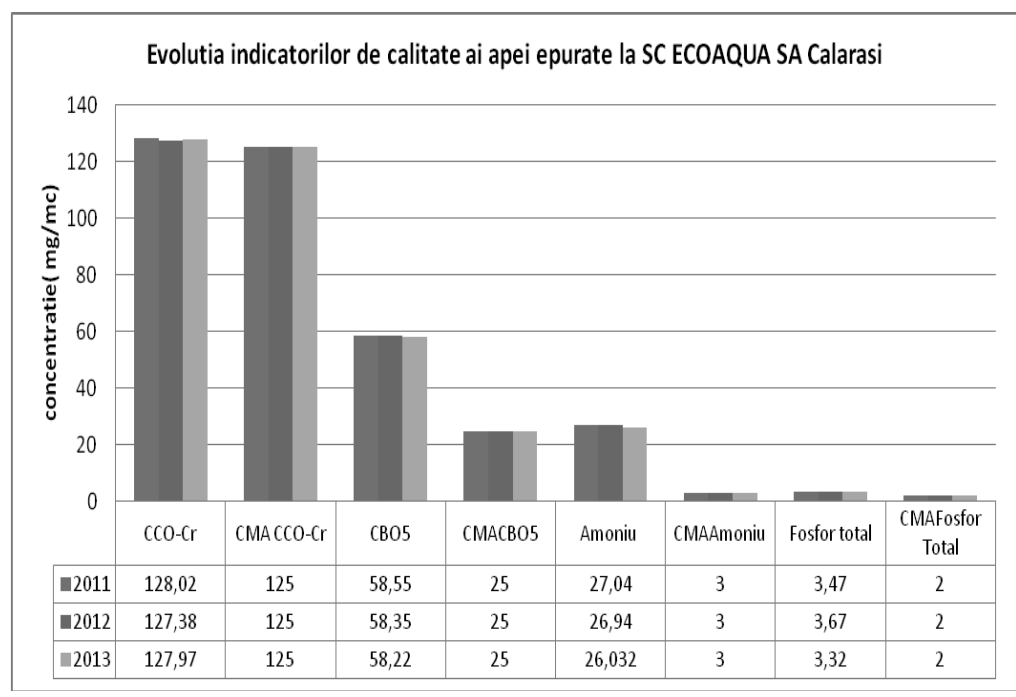

Fig.1. Indicators of quality of evacuated wastewater at SC ECOAQUA SA in the period 2011-2013

Following the analyzes made, it was found out exceeding to the indicators: chemical consume of oxygen, organic substances, ammonia nitrogen and total phosphorus, as shown in the following data (Tab. 1.):

From the above data we can see a sensible exceeding of the limit values to discharge into the environment for $\mathrm{CCO}-\mathrm{Cr}$.

For $\mathrm{CBO}_{5}$ the limit value limit to discharge into the environment is $25 \mathrm{MgO} / \mathrm{l}$. Determinations underline the value exceeded by $50 \%$.

For ammonia, the discharge into the environment is limited to $3 \mathrm{mg} / \mathrm{l}$, a value exceeded by approximately 9 times and total phosphorus limit value is $2 \mathrm{mg} / \mathrm{l}$, a value also exceeded about 1.5 times.

The exceeding was due to non-compliance, with repercussions on the quality of the natural receptor, the Danube.
From the analysis of data obtained in the period 2011-2013, the conclusion is that the conventional method of treatment applied in Waste Water Treatment Plant in Călăraşi town had not enough efficiency to get enough purified water.

In order to comply with the rules stipulated by the legislation in force, the mechanical treatment stage and chlorine disinfection are not enough.

Further discharge of untreated or poorly treated wastewater into surface waters will have serious consequences on the natural phenomenon of self-purification.

Exceeding the indicators: chemical consume of oxygen, organic substances, ammonia nitrogen and total phosphorus by the existing rules or NTPA $001 / 2005$ setting the limit values for pollutant load of the industrial and municipal wastewater discharged into natural receivers, complemented by NTPA 011/2002, which contains requirements 
relating to discharges derived from wastewater treatment plants proves ineffective way of unconventional treatment methods practiced. The important issue of effective treating is to reduce the nutrient loading and organic substances discharged into the Danube and Borcea branch.

In the recent years, as it can be seen from the above data, treated water is discharged into the Danube, discharge with high organic loading and eutrophication indicators.

The quality of wastewater discharged depends heavily on effective emissary treatment system. This led to the modernization of sewage and wastewater treatment system Călăraşi, so into the emissary is discharged water loaded with less impurities and the best possible treatment.

The negative impact on environment due to wastewater discharge into Borcea branch and thus into the Danube River was settled by the project implementation "Extension and rehabilitation of water supply and sewerage systems in Călăraşi county", approved by the European Commission, with funding from the Cohesion Fund. The project consisted of investments for drinking water treatment and distribution and wastewater collection and treatment.
The wastewater treatment plant belonging to SC ECOAQUA SA Călăraşi includes, after upgrading and modernization, the following components:

- Mechanical filtration step

- Biological step

- Chemical treatment of wastewater

- Mud treatment

- Installations for gas produced in the treatment plant

The combination of the three steps of treatment, mechanical, chemical and biological one was designed in order to achieve a high efficiency of removing impurities existing in raw sewage water for returning them to the circuit of the surface waters, at parameters approved by the norms in force.

Wastewater treatment is performed based on activated mud technology, including mechanical biological treatment steps, mud treatment with anaerobic stabilization and energy recovery from fermentation gas through co-generator block.

The results of examinations and tests conducted by the expertise ofAgency for EnvironmentProtection Călăraşi highlighted the effective treatment system and municipal wastewater treatment, thereby reducing the content of organic material discharged into the environment and also reducing the quantity of eutrophication agents - total phosphorus and ammonium ion, as shown in the following data:

Tab.2. Evolution of treatment system at SC ECOAQUA SA Călăraşi

\begin{tabular}{|c|c|}
\hline Type of treatment plant before funding & Type of treatment plant after funding \\
\hline Mechanical-chemical with treatment & Mechanical step \\
\hline efficiency $64 \%$ & Biological step \\
\hline Chemical indicators analyzed at & Chemical step \\
\hline discharge into emissary: chemical & Mud use \\
\hline consume of oxygen, organic & Treatment Efficiency $100 \%$ and mud use both for biogas production and for agriculture \\
\hline $\begin{array}{l}\text { substances, suspensions - with } \\
\text { exceeded values compared to norms } \\
\text { in force }\end{array}$ & $\begin{array}{l}\text { Chemical indicators analyzed at discharge into emissary: chemical consume of } \\
\text { oxygen, organic substances, suspensions - with values under those compared to } \\
\text { norms in force }\end{array}$ \\
\hline
\end{tabular}

Tab.3. Quality of treated wastewater at S.C. ECOAQUA Călărasi in the period November 2013 - April 2014 (Monthly reports, 2013, 2014)

\begin{tabular}{ccccccccc}
\hline \multirow{2}{*}{ Year } & \multicolumn{7}{c}{ Indicators of quality $(\mathrm{mg} / \mathrm{mc})-$ monthly values } \\
\cline { 2 - 9 } & $\mathrm{CCO}-\mathrm{Cr}$ & CMA & $\mathrm{CBO}_{5}$ & CMA & Ammonium & CMA & Total phosphorus & CMA \\
\hline November 2013 & 25.92 & $\mathbf{1 2 5}$ & 22.4 & $\mathbf{2 5}$ & 0.27 & $\mathbf{2 ( 3 )}$ & 3.16 & $\mathbf{1 ( 2 )}$ \\
\hline December 2013 & 41.75 & $\mathbf{1 2 5}$ & 20.7 & $\mathbf{2 5}$ & 0.02 & $\mathbf{2 ( 3 )}$ & 2.56 & $\mathbf{1 ( 2 )}$ \\
\hline January 2014 & 35.2 & $\mathbf{1 2 5}$ & 24.92 & $\mathbf{2 5}$ & 3 & $\mathbf{2 ( 3 )}$ & 2.86 & $\mathbf{1 ( 2 )}$ \\
\hline February 2014 & 32.87 & $\mathbf{1 2 5}$ & 32.87 & $\mathbf{2 5}$ & 2.75 & $\mathbf{2 ( 3 )}$ & 1.67 & $\mathbf{1 ( 2 )}$ \\
\hline March 2014 & 38.4 & $\mathbf{1 2 5}$ & 38.4 & $\mathbf{2 5}$ & 2.97 & $\mathbf{2 ( 3 )}$ & 1.74 & $\mathbf{1 ( 2 )}$ \\
\hline April 2014 & 34.28 & $\mathbf{1 2 5}$ & 34.28 & $\mathbf{2 5}$ & 0.46 & $\mathbf{2 ( 3 )}$ & 2.14 & $\mathbf{1 ( 2 )}$ \\
\hline
\end{tabular}




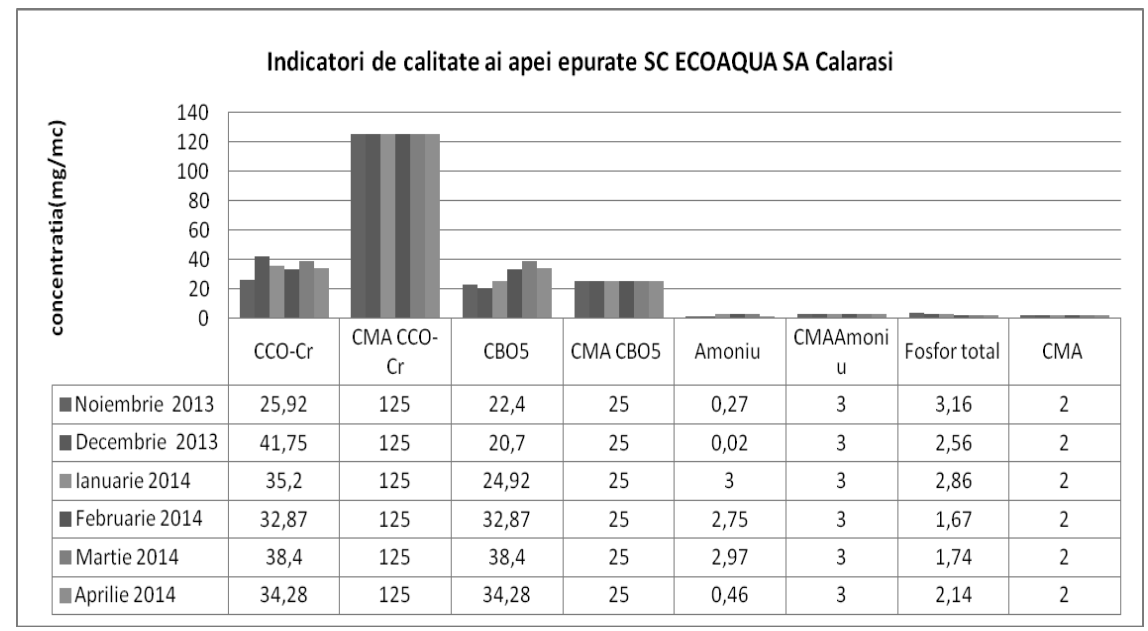

Fig. 2. Evolution of main indicators of quality determined in the treated water at S.C. ECOAQUA Călărasi in the period November 2013 - April 2014

From the evolution of the main indicators analyzed, is a decrease in content of organic substances and eutrophication indicators. Besides total phosphorus, which also exceeded the maximum $1.5 \%$ the other indicators monitored comply with the standards required by the legislation in force.

A second important source of area identified as source of pollution of Borcea branch and of the Danube River is the waste water from the meat processing factory and meat products in the town.

The wastewater from the food industry consist of water transport and washing of raw materials, process water, cooling water or condensate, water from washing and disinfecting the manufacturing rooms and packaging machinery, water from plumbing. The wastewater is characterized by a high variation of physicochemical and microbiological properties, due to the variety of their origin and composition.

From the meat processing plants, waste water coming from the slaughter of animals washing of digestive tube, meat processing, fat an animal skin.
It has a high content of organic substance, high quantities of nitrogen and phosphorous and at a temperature generally $30-40^{\circ} \mathrm{C}$.

Wastewater from the technological process of this unit works on the principle of biological treatment of active mud.

The method principle for the biological treatment of active mud is that micro-organisms are intimately mixed with wastewater containing organic material in the presence of oxygen, followed by flocculation of active mud of microorganisms that form which is active microbial mass. Active mud is the basic structural unit of biological treatment process, it contains all common species in their function and can metabolize organic substance to $\mathrm{CO}_{2}$ şi $\mathrm{H}_{2} \mathrm{O}$. Active mud can be defined by stopping aeration floaters sediment.

The results efficiency of introducing the modern methods of wastewater treating resulted from the production of this factory, representative for businesses in the county are given in the table below (analyzes were made in the laboratory of Agency for Environment Protection Călăraşi):

Tab.4. Indicators of quality of wastewater discharged into the environment between 2011-2013

\begin{tabular}{cccccc}
\hline Indicator & $\mathrm{UM}$ & $\begin{array}{c}\text { Limit } \\
\text { value } \\
\mathrm{CMA}\end{array}$ & 2011 & 2012 & 2013 \\
\hline $\mathrm{CCO}-\mathrm{Cr}$ & $\mathrm{mgO}_{2} / \mathrm{dm}^{3}$ & 125 & 69.29 & 79.85 & 51.5 \\
\hline $\mathrm{CBO}_{5}$ & $\mathrm{mgO} / \mathrm{dm}^{3}$ & 25 & 25.55 & 30.76 & 27 \\
\hline$\left[\mathrm{NH}_{4}^{+}\right]$ & $\mathrm{mgN} / \mathrm{dm}^{3}$ & $2.0(3.0)$ & 0.47 & 0.17 & 0.28 \\
\hline $\begin{array}{c}\text { Total } \\
\text { phosphorus }\end{array}$ & $\mathrm{mgP} / \mathrm{dm}^{3}$ & $1(2)$ & 3.14 & 3.38 & 3.63 \\
\hline
\end{tabular}


As we can see from the data presented, hardly biodegradable organic compounds do not cause problems for the evacuation in the emissary and no ammonia. In contrast, total phosphorus and biochemical oxygen shows very little exceeding.

The results of measurements and analyzes performed by the expertise of Agency for Environment Protection Călăraşi highlighted the efficiency of sewage and wastewater discharged into Jirlău river, then Borcea branch, thereby reducing the content of organic material discharged into the environment and also reducing the amount of eutrophication agents total phosphorus and ammonium ion.
Operating the parameters presented with organic loading and eutrophication parameters according to the legal norms, the environment impact is reduced, thereby preventing the pollution of surface water, soil and groundwater.

According to data from Buzău-Ialomița Basin Administration, following the analysis of the control sections taken from the Danube River Basin, in the sector corresponding to Călăraşi county, in the year 2013, the situation was as follows (tAB. 5.):

We see from the table 5. quite high quantities of nitrogen, phosphorus and organic substances hardly biodegradable which reach annually the Danube.

Tab. 5. Indicators of quality of the Danube water in the sector belonging to Calarasi county in 2013 (Environment report, 2013)

\begin{tabular}{ccc}
\hline Indicator & $\mathrm{UM}$ & 2013 \\
\hline $\mathrm{CCO}-\mathrm{Cr}$ & $\mathrm{mgO}_{2} / \mathrm{dm}^{3}$ & 253,906 \\
\hline $\mathrm{CBO}_{5}$ & $\mathrm{mgO} 2 / \mathrm{dm}^{3}$ & 67,42 \\
\hline$\left[\mathrm{NH}_{4}{ }^{+}\right]$ & $\mathrm{mgN} / \mathrm{dm}^{3}$ & 3,029 \\
\hline Total phosphorus & $\mathrm{mgP} / \mathrm{dm}^{3}$ & 0,3175 \\
\hline
\end{tabular}

\section{CONCLUSION}

The indicators of quality of wastewater discharged into the Danube did not fit into the last three years in the limits imposed by regulations in force (respectively NTPA $001-\mathrm{CBO}_{5}, \mathrm{CCO}-\mathrm{Cr}$, ammonium, total phosphorus), but since this year after re-technology of treatment station existing in town, this is much improved. However, waste water treatment plan is still under control of functional parameters.

Until the implementation of the modernization and refurbishment of Wastewater treatment plant of SC ECOAQUA SA Călăraşi during the technological processes performed inside the treatment plant of the town, there was a negative impact on the environment due to the values of pollutants concentration determined above.

In recent months, the treated water quality has improved from physical-chemical point of view.

From the evolution of the main indicators analysed, it is found out that the decrease of content of organic substances and eutrophication indicators, their values being closer to the standards required by the legislation in force, the treatment efficiency is quite good.

The project implemented in Călăraşi municipality led to:

- Improvement of quality of final effluent and the quality indicators fitted into the Romanian environment and European Union standards;

- Reduction of quantities of polluting substances discharged and protection of emissary against eutrophication;

- Reduction of air, soil and surface water pollution.

Regarding the study made at the meat processing factory, representative of the town and an important contribution of pollutants that reach the Borcea branch and then the Danube, a small piece of pollutants exceeding the total phosphorus concentration (an important agent of eutrophication) and organic substances.

We conclude that although in the recent years the efforts are large enough not to reach pollution due to nitrogen and phosphorus in the Danube terminal basin, there are still problems with a 
much lower proportion compared to last year discussed in this study.

We must not forget the significant amounts of nitrates and nitrates from the agricultural sector which make a significant contribution to the pollution of groundwater, and that they end up in the Danube.

Wastewater treatment is a main effort in the survival process of the species on earth, as it is well known that without water no body can survive over time and that is why we people should maintain clean and unpolluted the substance always present in our lives - water.

The identification of pollutants, the interpretation of their effects would have no major impact on the environment without the development of solutions and technical measures to combat the pollution.

There is need to establish a comprehensive regulatory framework for the control of pollution in Romania. Although there are already some provisions in force, in some cases they are fragmented and uncoordinated. In other cases, environment legislation and draft legislation on environment do not adequately take into account the current agricultural practices in Romania.

\section{REFERENCES}

1. Agency for Environment Protection Călăraşi - Annual reports on the situation of the environment factors in Călărași during the years 2011, 2012, 2013.

2. Agency for Environment Protection Călărași (November 2013-April 2014) - Annual reports on the situation of the environment factors in Călăraşi.

3. Berca M. (2006), Environment planning and natural resources management, Ed. Ceres, Bucharest, 284

4. Berca M. (2008), Soil ecology problems, Ed. Ceres, Bucharest, 16.

5. Code of good agricultural practices, vol I, (2003), Bucharest, 55.

6. Creţu D., Iova R.A. (2013), "Analysis of the natural potential and of the agricultural structures in the rural area", Scientific Papers Series "Management, Economic Engineering in Agriculture and Rural Development", USAMV Bucharest, Vol. 13, Issue 3: 69-72.

7. Iova R. A, Creţu D. (2012), "Sustainable development of local resources by ecotourism in Călăraşi county”, Scientific Papers Series "Management, Economic Engineering in Agriculture and Rural Development", USAMV Bucharest, Vol. 12, Issue 3: 79-84.

8. Neagu C.V., Muşat R. E. (2005) „Nitrite pollution in the Danube terminal basin", National simposium with international participation, USAMV Bucharest, Ed. Cartea Universitară; 284-289.

9. Şchiopu D. (1997), Ecology and environment protection, Didactical and pedagogical Publishing, Bucharest, 126127.

10. Şchiopu D. et al. (2002), Ecology and environment protection, Ed. „Ion Ionescu de la Brad”, 164. 